\title{
The Future of Poison Pills in Canada: Are Takeover Bid Reforms Needed?
}

\author{
by \\ Anita Anand
}

- The investor protection rules that apply in corporate takeover bids may soon undergo major changes in Canada. Provincial and territorial securities regulators have proposed a new national framework for the regulation of takeover bids, including the use of "poison pills" by target companies.

- A poison pill makes it prohibitively costly for the hostile bidder to obtain control of the target without the target board's cooperation. But, by empowering management and the board, the pill also places a wedge between the bidder and the target shareholders to whom it has made the offer. Issues of conflicted or entrenched directors and managers can also arise.

- Under the new framework, takeover bids must receive tenders of more than 50 percent of the outstanding securities subject to the bid. Bids must remain open for a minimum of 120 days; a significant increase from the current requirement of 35 days.

- The proposed 50 percent condition is commendable as it minimizes the impact of potential conflicts of interest at the board and senior management levels. However, a 120-day bid period is too long: it disadvantages both target shareholders and bidders by making bids more expensive while benefitting the board and management of the target. A 120-day bid period will ultimately serve to deter some takeover bids from occurring. I recommend the current time-period of 35 days, on which existing case law is based, should remain in place.

The rules governing takeover bids in Canada could soon undergo the most significant reforms in recent decades. The Canadian Securities Administrators (CSA), an umbrella organization comprised of provincial securities regulators, recently proposed a new national framework for the

This is an adapted and abridged version of an article that will be published in the McGill Law Journal. 2015. 61:1 Please cite with permission. The author wishes to thank Duncan Munn and Daniel Schwanen of the C.D. Howe Institute, as well as several anonymous reviewers, for their comments on earlier drafts. Responsibility for any errors and the views expressed here remains with the author. 
regulation of takeover bids. Under the CSA Proposal, takeover bids must receive tenders of more than 50 percent of the outstanding securities subject to the bid. The 50 percent condition means that a bid would succeed only if a majority of independent shareholders tendered their securities in response to the bidder's offer. Unless the target board prefers a shorter period, but in any event not less than 35 days, bids must remain open for a minimum of 120 days; a significant increase from the current requirement of 35 days.

The CSA Proposal is a watershed moment in Canadian securities regulation: it contains important substantive amendments to the legislative regime and represents a united front for the provincial and territorial jurisdictions that comprise the CSA. The CSA Proposal was released for comment until June 29, 2015 and now securities regulators are reviewing the comments.

In this E-Brief, I discuss the current regime, in which so-called "poison pills" figure large in the strategies to protect shareholders' rights, and identify weaknesses of poison pills in that regard. Against that backdrop, I assess the merits of the CSA Proposal in terms of investor protection and market efficiency. Among my conclusions: in its current form, the revised framework will likely lead to a reduction in the number of hostile takeover bids and will empower the management and board of target companies to hold up or prevent bids that shareholders may otherwise wish to succeed. Finally, I recommend changes to the proposed framework.

\section{Pick Your Poison}

Shareholder rights plans or "poison pills" are a form of defensive tactic that enables a corporation to shield itself against hostile or unwelcome bidders by making it prohibitively expensive for the bid to succeed. If triggered, the poison pill allows all existing shareholders, other than the original bidder, to purchase shares at a discount, which has the effect of diluting the bidder's holdings in the target and making its bid more expensive. ${ }^{1}$ The target may adopt a poison pill prior to any hostile bid being launched or it may do so in the face of a bid (a so-called "tactical" pill). Once shareholders ratify the pill, the decision rests with the board regarding whether to trigger it; in reality, this rarely happens as the hostile bidder typically negotiates with the target or launches a proxy contest to replace the target board altogether.

The pill thus provides the target board with a period of time which varies by takeover bid. That time can be used to negotiate with the bidder for an enhanced offer, to solicit competing bids or to propose alternative options to its shareholders (Kahan and Rock 2002). In the absence of either an improved offer or the emergence of alternative bidders, Canadian case law suggests that "the pill must go" and the original bidder can proceed with its proposed acquisition transaction (See Re Royal Host Real Estate Investment Trust (1999), 8 ASCS 3672). But poison pills, even those ratified by shareholders, take the decision about whether a bid proceeds out of the hands of shareholders. They leave the decision with management and the target board, who may not act in shareholders' best interests.

1 This is known as a "flip-in" provision (the most common type) which typically states that upon the acquisition of a certain percentage (10 or 20 percent) of the target's outstanding securities, each right other than those held by the bidder entitles its holder upon payment to acquire the target's securities having a market value equal to some multiple (e.g. two times) of the exercise price. See "Poison Pill" online: Macabacus <https://www.macabacus.com/defense/poison-pill>. 


\section{The Weaknesses of Poison Pills}

Because of the potential dilution effect of triggered pills, the pill (and by implication, the legal rules that permit the use of this defensive tactic) allows discrimination between the bidder and all other shareholders of the target. This discrimination runs contrary to the principle of equal treatment in securities regulation, embodied in provisions such as the identical consideration and pro rata take-up rules (Anand 2000). The objective of these provisions is to ensure all shareholders receive the same price for their shares and that all tendering shareholders receive the same proportion of shares purchased by the bidder in cases of a partial bid regardless of when they tendered (Securities Act (Ontario) RSO 1990, c S5, ss. 97(1) and 97.2(1)).

These defensive tactics were meant to prevent hostile bidders from encouraging target shareholders to tender to an unreasonably low bid. In theory, the pill makes it prohibitively costly for the hostile bidder to obtain control of the target without the target board's cooperation (MacIntosh 1989). But, by empowering management and the board, the pill also places a wedge between the bidder and the target shareholders to whom it has made the offer. The pill allows management and the board to bargain on behalf of shareholders, to seek out a higher or more attractive offer so that shareholders do not fall prey to the tactics of the hostile bidder (MacIntosh 1989). Without a pill, a bidder could exploit coordination problems among widely disseminated shareholders and pay less for control than if the target were to face an auction.

\section{Conflicted Directors and Managers?}

But placing the bargaining power with the board and management gives rise to a concern that these parties may be conflicted. As rational, self-interested actors, directors may well act in their own interests rather than in the corporation's, regardless of their ongoing fiduciary duty to the latter (Jensen and Meckling 1976). They may seek to "extract higher wages and larger perquisites from shareholders, and obtain more latitude in determining corporate strategy" (Shleifer and Vishny 1989). In the face of a hostile takeover bid where they may lose their positions following a change of control, they could potentially make decisions that have the effect of perpetuating themselves in office (See 347883 Alberta Ltd v Producers Pipelines Ltd (1991), 80 DLR (4th) 359 (Sask CA)).

A concern with management entrenchment contained in the Kimber Report provided the historic rationale of Canadian takeover bid law (Report of the Attorney General's Committee on Securities Legislation in Ontario). The Report also sought to ensure that shareholders receive adequate information, have time to make a reasoned judgment and receive equal and fair treatment. Some question the scepticism contained in what has come to be called the "management entrenchment hypothesis." First, one cannot determine with certainty that directors and management seek to entrench themselves in any given situation. Second, the theory ignores senior managers' and directors' attempts to fulfill their fiduciary duties. The OSC has recognized that the boards of directors of target companies genuinely attempt to fulfill their fiduciary duties to the corporation, holding that a measure of deference should be accorded to board decisions (See Re Neo Materials Technologies Inc, 2009 LNONOSC 638).

However, the question is not whether managers and the board will in fact put their own interests ahead of those of the corporation and its stakeholders, but whether they have the ability to do so. As long as management and the board have the opportunity to prioritize their own interests above the corporation's, management entrenchment remains a relevant concern. One could ask: why not then strip senior management and the board of their powers outside of the takeover context and let shareholders make all major decisions? The answer is that takeover contests are not the ordinary course of business. Given that there is a change of control on the immediate horizon, takeovers intensify the threat of management entrenchment as directors and senior managers 
contemplate a potential loss of board seats and/or employment. Thus, the applicable legal regime should minimize the impact of potential conflicts of interest at the board and senior management levels.

\section{The Legislative Rationale}

The legislative rationale for poison pills in Canada is set forth in the CSA's National Policy 62-202 - Takeover Bids - Defensive Tactics, which is currently in force and which articulates two underlying principles regarding a board's implementation of takeover defences:

1. Unrestricted auctions produce the most desirable results in takeover situations; and

2. Shareholders of the target should generally be given an opportunity to determine the ultimate outcome of the hostile bid by making a fully informed decision.

As a consequence of these principles, Canadian securities commissions have historically allowed target boards to use defensive tactics solely to attempt to obtain a better bid, rather than to reject a bid outright.

While this may sound straightforward, it is not the case in practice. The outcomes of poison pill cases tend to be fact-driven, and the factual scenarios vary from case to case (See Re Royal Host). Securities commissions, which are administrative bodies and are not required to adhere to a system of precedent, have held that a number of factors must be considered in making the determination of whether a defensive tactic can remain in place, including: whether the bid is coercive or unfair to target shareholders; when the pill was adopted; whether the board obtained shareholder approval of the pill; and the status of any auction process being conducted by the target to source a higher offer (See HudBay Minerals Inc. and Augusta Resource Corporation, (Re) 2014 BCSECCOM 153).

\section{Unwelcome Uncertainty}

This case-specific approach has led to inconsistent decisions and has therefore injected unwelcome uncertainty into the market (e.g., Neo Materials). This uncertainty arguably hampers the likelihood of bids, since market participants cannot know prior to a bid what rules will apply, whether the bid will be permitted to proceed or what the corresponding timeframe will be. Moreover, the decisions about whether a takeover bid proceeds should not rest only with the board or with the regulator, but with those who are most affected by the transaction: the shareholders of the target company.

One could argue that uncertainty is not necessarily disadvantageous to the target shareholders if it results from a period during which the board is exploring alternatives. Furthermore, one might argue that the board is best placed to protect the interests of shareholders because the board has access to information and can negotiate on their behalf. While this argument has some merit, it does not take into account the potential for management and the board to search for alternatives that are more self-serving than the original offer. The lengthier the bid period, the more leeway for the board to delay or forgo decisions that may be in the shareholders' best interests.

\section{Reform of Takeover Bid Regime?}

In light of the uncertainty emanating from the case law, the question persists as to whether reform of Canada's takeover bid law regime, including those changes contemplated in the CSA Proposal, is warranted. The CSA Proposal seeks to strike a certain balance between the interests of target shareholders and the target board. Under the CSA Proposal, bids would be subject to a mandatory (i.e., unwaivable) minimum tender condition of 
more than 50 percent of all outstanding target securities of the class subject to the bid, excluding those held by the bidder and its joint actors.

The 50 percent condition means that a bid would succeed only if a majority of independent shareholders tendered their securities in response to the bidder's offer (since, as noted, securities of the bidder and those acting jointly or in concert with the bidder are excluded from the 50 percent). Once this and other regulatory conditions are met, the CSA Proposal imposes an additional ten-day right to tender for undecided shareholders (provided that all other terms and conditions of the bid have been complied with or waived).

Further, the 50 percent minimum tender condition is consistent with the arguments above, as it weighs in favour of shareholder decision-making. The underlying rationale is that in a hostile bid, "each shareholder must ultimately be given access to an offer and the opportunity to tender" (Tory et al. 2010).

Akin to a shareholder vote, this approach affords majority shareholders the ability to determine whether the takeover bid will succeed. Minority shareholders who wish to tender, but whose views deviate from the majority who do not tender, will not have their shares taken up pursuant to the bid. In an era where institutional shareholders are increasingly sophisticated (MacIntosh 1993), it makes sense to allow bidders to "speak to" target shareholders directly - especially in the case of poison pills that are not approved by shareholders.

One might legitimately argue that this aspect of the CSA Proposal may mitigate against partial bids and may give veto power to large shareholders. It may also effectively ban any and all bids in which bidders are willing to take up any tendered shares without a minimum tender condition. But, importantly, it will not force shareholders out unless the bidder completes a forced buyout under corporate law.

\section{Why the 120-day Bid Period is Ill-conceived}

The minimum tender condition will prevent bidders from being able to corner target shareholders into the undesirable choice of selling into an underpriced offer or being stuck with illiquid shares (Anand 2015). While this aspect of the CSA Proposal is commendable, the 120-day bid period is ill-conceived. Hostile bidders will likely feel exposed under the 120-day period, since their bid remains open and a rival bidder, perhaps more supportive of management, can come forward during this time (MacIntosh 1991). Further, the longer time a bid must be outstanding will lead to more expensive and riskier financing. Financial resources that bidders have allocated to purchase the target's shares remain in limbo (i.e., unusable) while the 120-day clock runs, leading to greater inefficiencies.

The 120-day bid period will, as a result, deter some bids and certainly hostile bids from occurring, which is sub-optimal from both an economic efficiency perspective and an investor protection standpoint. It is true that the target board can reduce the 120-day period as it might in a friendly transaction. If it does, the bid must remain open for a minimum of 35 days and all contemporaneous bids would be subject to the same shorter deposit period.

My view, however, is that 35 days, the current minimum period under the Securities Act (Ontario), should be the ceiling, not the floor, in terms of the time during which the target board has to act. The reason: this time period is known to the market and strikes a balance between the interests of the target and the bidder (who seeks to complete the deal as quickly as possible). The justification for such a lengthy bid period, including the negative implications for target shareholders, bidders and takeover bids generally, is not clear from the CSA Proposal.

If implemented, the CSA Proposal means that specific requirements relating to majority approval and bid periods will govern takeover bids. The law relating to takeover bids will, therefore, be more certain and will 
lead to less poison pill litigation - both positives for shareholders. However, instead of relying on poison pills, target boards can easily implement other defensive tactics (asset sales or private placements, for example) as they will have a lengthy period of 120 days in which to do so. It seems plausible that regulatory intervention may occur as a result of tactics other than poison pills. Furthermore, nothing seems to prohibit target boards from implementing tactical pills prior to the expiry of the 120-day bid period. With no national securities regulator in place, it is also possible provincial regulators will address tactical pills differently in proceedings before the respective commissions and the fragmentation that has plagued the takeover bid regime in the past will continue.

\section{Conclusion}

Poison pills adopted without shareholder approval isolate shareholders during a crucial decision about the firm in which they have invested. As long as the potential for conflict between the interests of boards and those of shareholders remains, shareholders should be able to decide the fate of their investment.

In this regard, the 50 percent condition proposed by the CSA is commendable as it minimizes the impact of potential conflicts of interest at the board and senior management levels. However, a 120-day bid period is too long: it disadvantages both target shareholders and bidders by making bids more expensive while benefitting the board and management of the target. A 120-day bid period will ultimately serve to deter some takeover bids from occurring. Given the market discipline and capital allocation efficiency benefits derived from takeover bids, it is counterintuitive for securities commissions to craft takeover bid rules that have the effect of discouraging bids. I

recommend that the CSA adopt the 50 percent condition but remove the 120 -day bid period provision. Instead of 120 days, the current time period of 35 days, on which existing case law is based, should remain in place. 


\section{References}

Anand, Anita. 2015. "New Canadian Securities Administrators' Rules would discourage takeover bids," The National Post. April 1).

Anand, Anita. 2000. "Regulating Issuer Bids: The Case of the Dutch Auction." McGill Law Journal (45):133.

Condon, Mary, et al. 2010. Securities Law in Canada: Cases and Commentary, 2d ed. Toronto: Emond Montgomery.

Jensen, Michael C., and and William H Meckling. 1976. "Theory of the Firm: Managerial Behaviour, Agency Costs, and Ownership Structure." Journal of Financial Economics (3): 305 .

Kahan, Marcel, and Edward B. Rock 2002. "How I learned to Stop Worrying and Love the Pill." University of Chicago Law Review (69): 871.

MacIntosh, Jeffrey G. 1989. "The Poison Pill; A Noxious Nostrum for Canadian Shareholders." Canadian Business Law Journal (CBLJ) (15):276.

1991. "Poison Pills in Canada: A Reply to Dey and Yalden" in (1991) 17 CBLJ 323 at 334 ["A Reply to Dey and Yalden"], written in reply to Peter Dey and Robert Yalden, "Keeping the Playing Field Level: Poison Pills and Directors' Fiduciary Duties in Canadian Take-Over Law" (1991) 17 CBLJ 252 and Robert Yalden, "Canadian Mergers and Acquisitions at the Crossroads, (2014) $C B L J(55): 389$.

- 1993. “The Role of Institutional and Retail Investors in Canadian Capital Markets.” Osgoode Hall Law Journal 31 (2):371.

Shleifer, Andrei, and Robert W, Vishny. 1989. "Management Entrenchment: The Case of ManagerSpecific Investments.” Journal of Financial Economics (25): 123.

Tory, James C. et al. 2010. “Canadian securities regulators' decisions on poison pills diverge.”July 30. Accessed online at: Torys <www.torys.com. 


\section{Legal Citations and Reports}

347883 Alberta Ltd v Producers Pipelines Ltd (1991), 80 DLR (4th) 359 (Sask CA)

HudBay Minerals Inc and Augusta Resource Corporation, (Re) 2014 BCSECCOM 153.

Lions Gate Entertainment Corp., 2010 BCSECCOM 432.

Re Baffinland Iron Mines Corp., 2010 LNONOSC 904.

Re Neo Materials Technologies Inc., 2009 LNONOSC 63.

Re Royal Host Real Estate Investment Trust (1999), 8 ASCS 3672.

Ontario Securities Act, R.S.O. 1990.

Ontario Securities Commission. 2015. CSA Notice And Request For Comment Proposed Amendments

To Multilateral Instrument 62-104 "Take-Over Bids And Issuer Bids Proposed Changes To

National Policy 62-203," and “Take-Over Bids And Issuer Bids And Proposed Consequential

Amendments," OSC CSA Notice, (31 March). Accessed online at: Ontario Securities

Commission.,<http://www.osc.gov.on.ca/documents/en/Securities-Category6/csa_20150331_62-

104_rfc-proposed-admendments-multilateral-instrument.pdf $>$.

Report of the Attorney General's Committee on Securities Legislation in Ontario. 1965. Toronto:

Queen's Printer.

This E-Brief is a publication of the C.D. Howe Institute.

Anita Anand is Professor of Law, Faculty of Law, University of Toronto and Fellow-in-Residence, C.D. Howe Institute.anita.anand@utoronto.ca.

This E-Brief is available at www.cdhowe.org.

Permission is granted to reprint this text if the content is not altered and proper attribution is provided. 